\title{
British Official Development Assistance (ODA) and the 2008 Financial Crisis: a Noteworthy Commitment or a Self-interested Strategy?
}

L'Aide publique au développement britannique et la crise financière de 2008 :

engagement exemplaire ou stratégie intéressée?

\section{Ondine Aza}

\section{(2) OpenEdition}

\section{Journals}

Electronic version

URL: http://journals.openedition.org/rfcb/1082

DOI: $10.4000 /$ rfcb.1082

ISSN: 2429-4373

\section{Publisher}

CRECIB - Centre de recherche et d'études en civilisation britannique

\section{Electronic reference}

Ondine Aza, « British Official Development Assistance (ODA) and the 2008 Financial Crisis: a Noteworthy Commitment or a Self-interested Strategy? ", Revue Française de Civilisation Britannique [Online], XXI-2 | 2016, Online since 08 October 2016, connection on 01 May 2019. URL : http:// journals.openedition.org/rfcb/1082; DOI : 10.4000/rfcb.1082

This text was automatically generated on 1 May 2019.

\section{c)}

Revue française de civilisation britannique est mis à disposition selon les termes de la licence Creative Commons Attribution - Pas d'Utilisation Commerciale - Pas de Modification 4.0 International. 


\section{British Official Development Assistance (ODA) and the 2008 Financial Crisis: a Noteworthy Commitment or a Self-interested Strategy?}

L'Aide publique au développement britannique et la crise financière de 2008 : engagement exemplaire ou stratégie intéressée?

Ondine Aza

\section{Introduction}

1 Official Development Assistance (ODA) is the international indicator of aid worldwide. It is managed by the Development Assistance Committee (DAC) of the Organisation for Economic Cooperation and Development (OECD). The European Recovery Program (known as the Marshall Plan) funded by the United-States and which provided capital and technical expertise to boost European economies after World War II influenced the setting up of the DAC in 1961, marking a new approach to cooperation in policy-making. ${ }^{1}$

In 1969, the concept of Official Development Assistance was adopted and since 1972, it has been defined as

"Flows to developing countries and multilateral institutions provided by official agencies, including state and local governments, or by their executive agencies, each transaction of which meets the following test: (1) It is administered with the promotion of the economic development and welfare of developing countries as its main objective and (2) it is concessional in character and contains a grant element of at least 25 per cent (calculated at a rate of discount of 10 percent)." ${ }^{2}$

3 The indicator used to evaluate donor country aid participation is the ratio ODA: Gross National Income (GNI). In 1970, the United Nations adopted the target of a ratio for ODA 
to GNI of 0.7 and donor countries were invited to reach this target during the decade. Only 4 countries have done so. ${ }^{3}$ In 2000, the UN issued the United Nations Millennium Declaration where it pledged to fulfil a series of targets by 2015. These targets are known as the 8 Millennium Development Goals (MDG). One of them is a pledge to develop a global partnership for development and donor countries renewed their pledge to reach the 0.7 target by 2015. In 2004, the UK government vowed to reach this target by $2013 .{ }^{4}$

In the present article, the terms aid, development aid or ODA are used to refer to the same concept. Countries sometimes use their own indicators to measure aid spent. For instance, the UK also uses an indicator called the Gross Public Expenditure on Development (GPEX). This indicator is different form ODA, namely because it is calculated for the financial year whereas ODA is calculated by calendar year. ${ }^{5}$ Since ODA is the main international measure of aid spent and is also applied by all donor countries, we use it here to make comparisons between the UK and other DAC countries.

In practice, aid can be made up of material, human, financial or other types of resources. ${ }^{6}$ It can either be directly transferred from the donor country to the recipient country bilateral aid - or through appointed organizations which pool resources from several donor countries and allocate them to countries or projects - multilateral aid. As stated in the definition of ODA, soft loans for development projects where the rate of interest is below market rates and for which the repayment does not cover the full initial capital can also be reported as ODA, as do equity investments if they are carried out by official agencies for development purposes.

6 For aid to be ODA-compliant, it has to flow from a donor country to a recipient country, both of which feature on DAC official lists. There are currently 29 donor countries and 146 recipient countries and territories. ${ }^{7}$ In practice, part of the amount declared as ODA never actually reaches recipient countries. ${ }^{8}$ Indeed, ODA is a measure centred on donor countries. Unbundling aid reveals that projects and campaigns to boost support for overseas development, global citizenship lessons in donor country schools, cancellation or rescheduling of debts and administrative expenditures linked to the management of ODA are all reported ODA. The OECD average of aid which definitely never reached recipient countries was roughly $20 \%$ for 2011 whereas that proportion for the UK stood at $8.6 \%{ }^{9}$

7 The paper will address the issue of how British ODA has fared in recent years and it will try to understand the trends that can be observed. The first part presents statistical data concerning ODA in the UK and the rest of the world, highlighting the characteristics of British ODA. Indisputably, the performance of the UK as a donor country stands out and the next part attempts to account for the resilience of British ODA since the 2008 financial crisis. The concluding remarks put forward some propositions to explain the long-term drivers of Britain's commitment to aid.

\section{Development Assistance in times of crisis and recession: the UK stands out}

\section{International trends}

8 Aid is only one of the several types of international flows that reach developing countries and it accounts for an extremely small share. In 2011, ODA represented $7.1 \%$ of all flows 
into developing countries..$^{10}$ Other flows include remittances, Foreign Direct investment, Loans, Military expenditure and development cooperation not governed by DAC rule. Overall, ODA has been one of the types of flows least impacted by the 2008 crisis. ${ }^{11}$ However, it has nonetheless been vulnerable to world crises, ${ }^{12}$ although the effects were not always felt immediately. After a period of steady increase from 2000 to $2010\left(+63 \%{ }^{13}\right)$, world ODA dropped by $2 \%$ in 2011 and further fell by $4 \%$ in $2012^{14}$ (Figure 1). This reflects the impact of the 2008-2009 financial crisis which plunged developed nations into recession, therefore reducing the amount of resource flows from donor countries to recipient countries in 2011 and 2012. But the decline was temporary and ODA picked up again. Data for 2013 shows an increase of 6.1\% on 2012 figures and 2013 and 2014 amounts are equal. ${ }^{15}$

Figure 1 - World ODA 2000-2014 (2014 price and exchange rates)

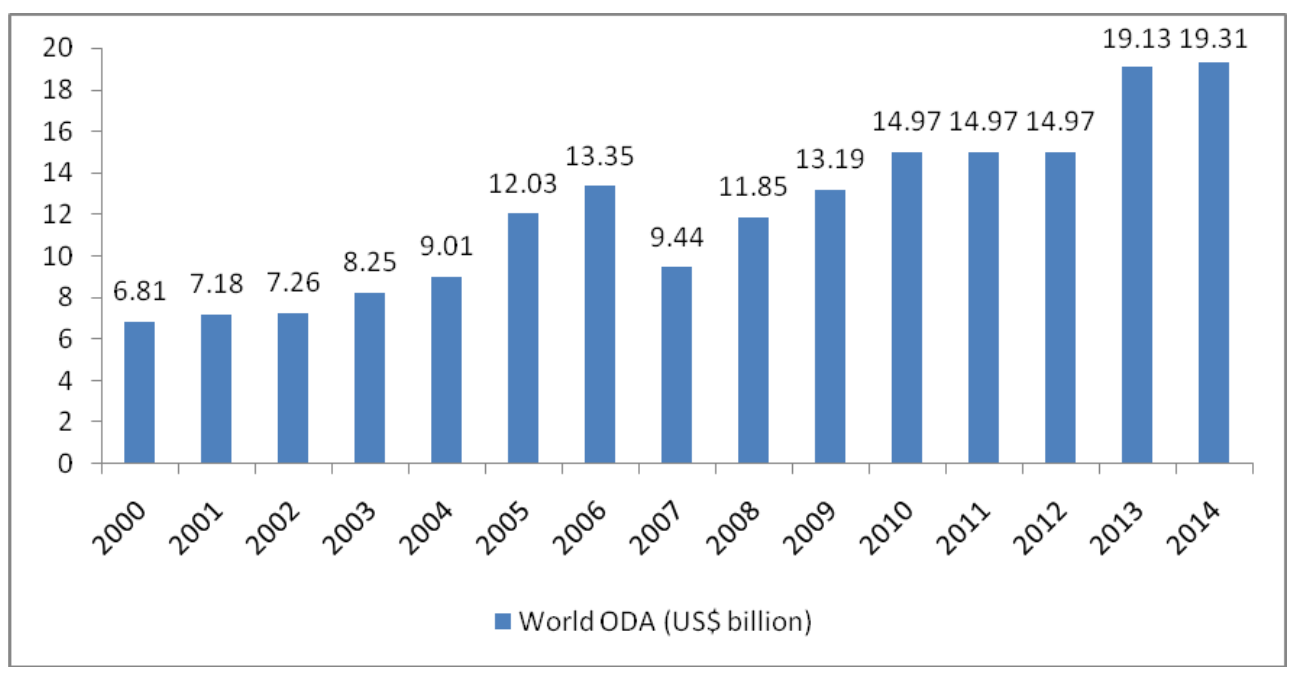

SOURCE: OECD STATISTICS [ONLINE] <HTTP://WWW2.COMPAREYOURCOUNTRY.ORg/ODA? CR=20001\&CR $1=0 E C D \& L g=E N \& P A g E=1 \#>[16 T H$ JUNE 2015]

The UK is one of the few countries to have actually achieved the target of ratio ODA: GNI of 0.7. It did so for the first time in 2013. The DAC average ratio is roughly 0.3. The other countries to have ever reached the 0.7 target are Denmark, Norway, Luxembourg, Sweden and the Netherlands. For the period 2008 to 2014, the ODA: GNI ratio for the UK progressively increased while the aforementioned countries maintained their aid budgets above 0.7 of their GNI, amidst fluctuations, with the exception of the Netherlands which slipped below the mark in 2013 and 2014.

The UK stands out not only because it is one of the few countries to dedicate 0.7 of its GNI to its aid budget but also because it is the only major donor in terms of volume of ODA to do so. The UK is the second largest donor, behind the United States but amongst the five largest donors, it is the only one to have fulfilled its pledge in terms of ODA to GNI ratio. With the exception of France for which the ratio ODA: GNI has progressively declined since 2010, the US, Germany and Japan, which are the other largest donors by volume, have globally maintained a stable ODA to GNI ratio since 2008 . 


\section{The UK's ODA}

11 The ratio ODA: GNI for the UK almost doubled in barely 6 years, from 0.36 in 2007 to 0.71 in 2013 (Figure 2). For the latter year, the top five recipients of British bilateral aid were Pakistan, Ethiopia, Bangladesh, India and Nigeria. Amongst these, only Ethiopia has never been a British colony. In 2013, 7 out of the 20 largest recipients of British ODA were former colonies. The UK does not officially favour former colonies as aid recipients, ${ }^{16}$ which statistics for 2011 tend to confirm. Indeed, 33\% of British bilateral aid went to 37 countries on the DAC list, which are also members of the Commonwealth. ${ }^{17}$ The 3 main sectors that received British aid in 2011 were Health, Education and Governance, totalling $45 \%$ of the total volume of aid. ODA accounted for $20 \%$ (US $\$ 13.8$ billion) of the international flows leaving the country in $2011 .{ }^{18}$

Figure 2 - ODA from the UK 1970-2014 (2014 prices and exchange rates)

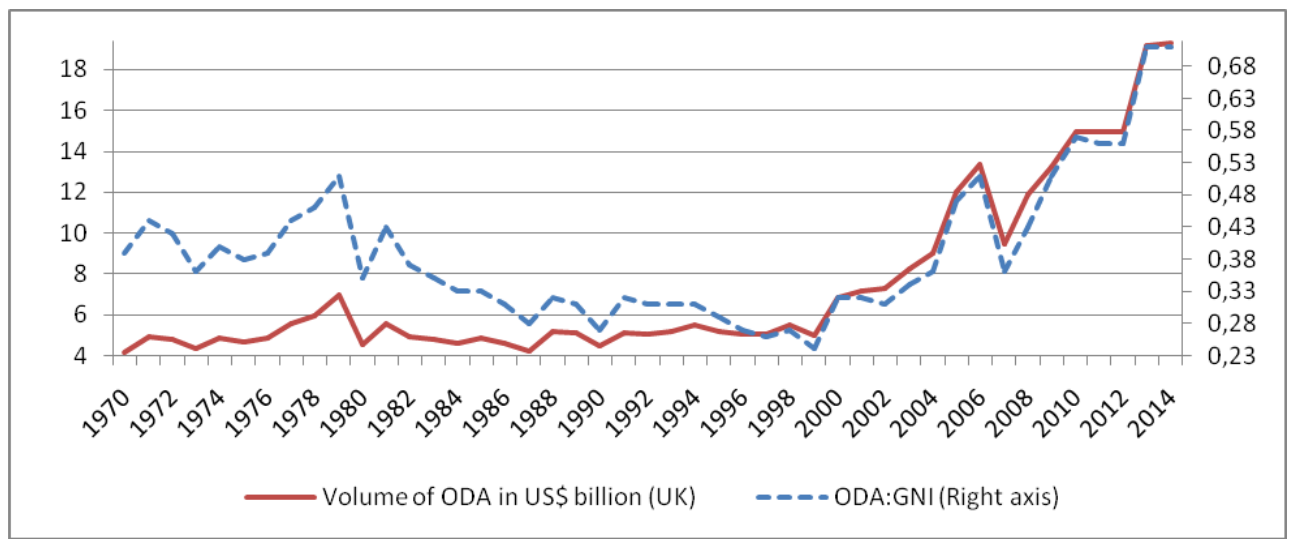

SOURCE: OECE STATISTICS [ONLINE] <HTTP://WWW2.COMPAREYOURCOUNTRY.ORg/ODA? CR=20001\&CR $1=0 E C D \& L g=E N \& P A g E=1 \#>$ [16TH JUNE 2015]

Achieving such an increase in aid at a time where many countries, including the UK, are facing budget constraints raises the question of how this was achieved. We asked ourselves if in the process of increasing the volume of ODA, the UK had also reviewed how it was allocated. We used data for the period 2000-2014, since the marked upwards trend of ODA started around the turn of the century. Overall, amidst fluctuations, the share of ODA channelled through multilateral organisations has slowly been gaining over that of bilateral ODA. ${ }^{19}$ The significance of this is ambiguous since there is no consensus on the relative superiority of one channel of aid over the other in terms of efficiency. ${ }^{20}$

Furthermore, within bilateral British ODA, we have grouped spending into three broad categories, to see if the composition of UK aid was shifting from more grants to more loans and equities and from more transferred aid to higher proportions of reported aid not leaving the country. Table 1 below summarizes our findings:

Table 1: Average composition of UK bilateral ODA 2000-201421

\begin{tabular}{|l|l|l|l|}
\hline & $\mathbf{2 0 0 0 - 2 0 0 4}$ & $\mathbf{2 0 0 5 - 2 0 0 9}$ & $\mathbf{2 0 1 0 - 2 0 1 4}$ \\
\hline Grants likely to be transferred to recipients & $59.6 \%$ & $64.0 \%$ & $60,01 \%$ \\
\hline
\end{tabular}




\begin{tabular}{|l|l|l|l|}
\hline $\begin{array}{l}\text { ODA not transferred (Administrative costs and debt } \\
\text { relief) }\end{array}$ & $13 \%$ & $17,58 \%$ & $6,6 \%^{22}$ \\
\hline Loans and equity & $4.6 \%$ & $1.95 \%$ & $3,25 \%$ \\
\hline
\end{tabular}

Source: DfID STATISTICS [Online], <https://www.gov.uk/government/organisations/department-forinternational-development/about/statistics>, [2 ${ }^{\text {nd }}$ June 2016]; OECD, Development Co-operation Peer Reviews: United Kingdom 2006, (Paris, 2006), p. 79; OECD, Development Co-operation Peer Reviews: United Kingdom 2010, (Paris, 2010), p. 98; OECD, Development Co-operation Peer Reviews: United Kingdom 2014, (Paris, 2014), p. 103.

Overall, Table 1 shows that the increase in ODA did not fundamentally alter its composition. Such a low share of bilateral loans and equity for the period 2010-2014 is somewhat unexpected, since the coalition government had indicated that these modes of ODA were preferred over grants as they did not have an impact on the public debt. However, it is possible that some loans and equity ODA are also channelled through multilateral organisations. ${ }^{23}$ Further analysis of how the different multilateral organisations receiving British ODA allocate it would be required to get a fuller picture. Without being entirely conclusive evidence, the progressive increase of multilateral ODA and the guidelines spelt out by the Treasury would seem to indicate that the composition of British ODA has probably evolved towards a greater share of non-grant ODA while increasing in absolute amount.

Not only was the volume of British aid not abated by the crisis, but on the contrary, the amount increased significantly to enable the UK to respect its commitment of allocating $0.7 \%$ of its GNI to ODA. How can we account for this resilience of ODA in an environment of otherwise shrinking public funding? What explains that other large donors have not yet followed in its footsteps? The answer lies in part in the creation in 1997 of the Ministry responsible for managing British aid, the Department for International Development (DfID), which marked both a new commitment of the British government to development objectives and a foreign policy where aid plays a role in repositioning the UK as an important global actor.

\section{Accounting for the resilience of British ODA since 2008}

\section{A changing international context}

The election of Labour, led by Tony Blair, in 1997 signals a new change in British aid policy. Part of this change can be attributed to a different way of viewing aid but part of it is also the result of a different context. Worldwide, the attitude and role of rich countries in international development was changing. The Brandt Report, published in 1980 recommended increasing the aid budgets, focusing on the poorest countries and resorting to multilateral institutions to administer aid. Whereas the 1980s and the 1990 s had been characterised by a period where aid was increasingly tied to a country's commercial interests, a consensus progressively seemed to emerge about the need to de-link aid from export concerns but instead, inscribe it in a broader strategy to reduce poverty. In addition, amidst the context of the Cold War, aid had been administered along with security issues and strategic decisions of which countries to support. By 1997, the context 
had changed and New Labour was able to put forward that their foreign policy would be guided by ethical concerns. ${ }^{24}$

Figure 3 shows that towards the second half of the 1990s, British ODA to GNI ratio begins to pick up, after slowly declining since the end of the 1970s. It also highlights the distinctive upwards trend of British aid when compared to the average for other donor countries from the mid-1990s onwards.

Figure 3 - ODA: GNI ratio UK and DAC average

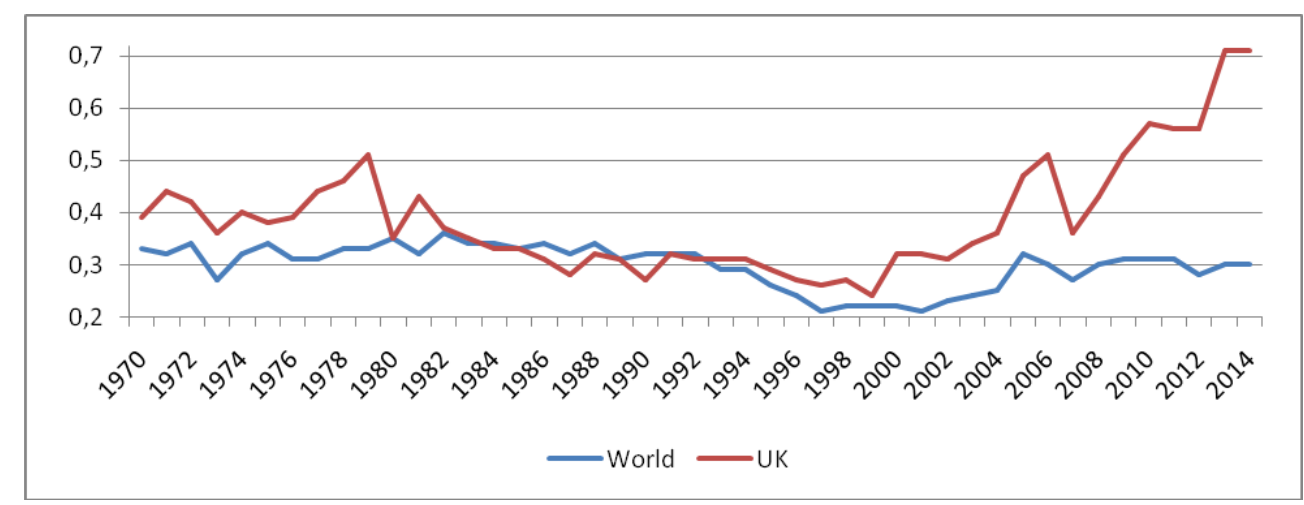

SOURCE: OECE STATISTICS [ONLINE] <HTTP://WWW2.COMPAREYOURCOUNTRY.ORg/ODA? $C R=20001 \& C R]=0 E C D \& L g=E N \& P A g E=1 \#>[12 T H$ MAY 2015]

\section{A political will}

18 The orientation and development of the DfID is arguable closely linked to Tony Blair's approach to Foreign policy. He believed that the UK should engage in international interventionism..$^{25}$ According to his doctrine on international community presented during a speech in Chicago in 1999, nations were increasingly interdependent and there was no separation between national interest and international collaboration. This interdependence implied that foreign policy and domestic policy were often intertwined. He believed interventionism to be a moral imperative in cases where massive numbers of civilians suffered. ${ }^{26}$

The Department for International Development (DfID) was created in 1997 as a distinctive, independent government department and whose Minister was a prominent member of the Cabinet. Prior ministries had almost always been subordinated to the Foreign Office. ${ }^{27}$ The Secretary of State for International Development, Clare Short, was the driving force behind the department during Blair's first term. ${ }^{28}$ The DfID placed the focus on development, not solely aid. As a result, aid was viewed as a means, not an end. Aid was meant to help create the right conditions within which countries could develop. Labour built a specific approach to deal with this new department. It published a White paper in 1997, the first in 22 years and then another one in 2000. It issued public statements on the government's approach and provided explanation to communicate about its actions to the British public and international stakeholders. It acknowledged that economic growth and liberalization were essential in the context of globalisation so emphasis was put on helping poor countries benefit from globalisation, rather than resist it..$^{29}$ In 2002, Parliament passed the International Development Act, whereby the UK committed itself by law to reject the use of aid to serve British commercial interests. In 
keeping with its official position that aid should first and foremost maximize development, under Labour, the DfID favoured grants over loans and equity financing, on average more than other donor countries. ${ }^{30}$

\section{0 and onwards, new governments but a will to maintain high levels of aid}

The target of reaching the 0.7 ratio of ODI: GNI was for a long time, a purely rhetorical aim. However, in 2004, the then UK Secretary of State for International Development, Hilary Benn and the Chancellor of the Exchequer, Gordon Brown actually indicated 2013 as their set year and budgeted for this increase. ${ }^{31}$ Despite the fact that the New Labour government in office in 1997 was replaced by a Conservative-Liberal Democrat coalition government in 2010, meeting this target remained a priority and in order to do so, the budget was increased in such a way that from 2012 to 2013, the ratio ODI: GNI jumped from 0.56 to $0.71 .^{32}$

The coalition government increased emphasis on the DfID's commitment to promote stability and end extreme poverty, namely through boosting economic growth and creating jobs in developing countries, while honouring the pledge of achieving the MDG. ${ }^{33}$ With a view to fostering stability, the government outlined a strategy named the "Building Stability Overseas Strategy" in 2011 where it committed itself to allocating 30\% of UK ODA to "fragile and conflict-affected states" and to increase the amount given to pooled resources. ${ }^{34}$ The focus on economic development has led the department to recruit more private sector specialists and be even more mindful of processes that actually produces results.

While still not resorting to non-grant forms of ODA to a significant extent, the current Conservative government, elected in 2015, intends to increase the use of loans and equity, ${ }^{35}$ all the while reporting low amount of non-transferred aid such as student costs, refugee costs and debt relief as ODA.

\section{Conclusion: The long-term drivers of the UK's commitment to development assistance}

\section{Prestige and international influence and reputation}

Since 1997, under Tony Blair, the UK has strived to play an important role on the forefront of the international scene. He endeavoured to rekindle the special bond between the USA and the UK and to foster links with the EU as well. ${ }^{36}$ The DfID played a role in this strategy. It expressed a willingness to work in collaboration with other donors and organization such as the World Bank, which also partly explains that it enjoys a high international reputation in the field of aid. ${ }^{37}$ An independent review by the Centre for Global Development and the Brookings Institution ${ }^{38}$ produced a positive assessment of the quality of UK's aid in 2014 in their third report on the Quality of ODA. Amongst the major donor in terms of volume of ODA, the UK definitely stands out, ranking in the top third on three of the four dimensions of aid quality, namely for maximizing efficiency, fostering institutions and reducing burden. ${ }^{39}$ As a former colonial power keeping close links with its former Empire through the Commonwealth, the British government has expressed its 
belief that it has a major role to play in improving the lives of millions of people throughout the world. Several official documents have reasserted this, amongst which a DfID report on "UK aid: Changing lives, delivering results" from 2011 which mentions the wish to "Re-emphasize the importance of the Commonwealth." 40

\section{Foreign policy strategy}

Empirical research on donor motivation highlights that providing aid is a component of foreign policy which serves a purpose not solely humanitarian. It can strengthen strategic, economic or ideological components of that foreign policy. ${ }^{41}$ Figure 3 highlighted that British ODA followed a trend which set it apart from the DAC average. In addition, it is the only major donor (in terms of amount of ODA) to have reached the 0.7 target. It is intriguing that the UK is, in a way, in a group of its own. A thorough examination of why this is so would require a full comparative analysis, to understand the motivations of all the donor countries of the DAC and to understand what pushed the UK to take such a lead. While the scope of such an analysis is beyond what we can achieve in this article, understanding that aid is part of a wider foreign policy strategy sheds light on what distinguishes the UK from other donors. ${ }^{42}$ Internationally, Britain's dwindling position as a world superpower throughout the $20^{\text {th }}$ century had left it with considerably less influence than it had previously enjoyed. Domestically, amidst fluctuations, ODA generally decreased during Margaret Thatcher's premiership from 1979 to 1990 and the ratio ODA: GNI which stood at 0.51 at the beginning of her term had fallen to 0.27 eleven years later. Tony Blair's belief in international interventionism implied restoring Britain's importance as a world power. In this light, a change of attitude towards aid was one of the components which would serve Britain's strategic international interests ${ }^{43}$ and which could also set it apart from the previous Conservative governments. The good reputation the DfID garnered, a repositioning of Britain on the international scene as a bridge between the European Union and the United States ${ }^{44}$ and Britain's several publicized commitments to aid ${ }^{45}$ ensured that the same course was kept when the Conservative-led coalition replaced Labour in 2010. The coalition government even enshrined its pledge to meet the 0.7 target by law. ${ }^{46}$ In a way, although part of Labour's strategy to restore the image of the party and positioning the country as an important player on the international scene, such endeavours benefitted ODA durably as proven by the coalition government spectacular effort to meet the 0.7 target in 2013 .

In comparison, the United States, which provides the largest amount of ODA, already enjoys a position of hegemony internationally. Indeed, it is the largest economy in terms of GDP and a leader in world diplomatic relations. Research has shown that American aid has tended to defend an ideological stance in favour of democratic regimes and to defend military strategic interests. Indeed, owing to its world power status and large investments in several countries, it is keen to protect its numerous and valuable interests. ${ }^{47}$ As such, the motivation to provide aid and the pattern of US aid is different from that of the UK. In the case of France, a former major colonial power like the UK and one of the largest ODA contributors, we may wonder why it has not yet achieved the 0.7 ratio. Like all western countries, it was affected by the 2007 financial crisis but unlike the UK, aid is one of the areas where funding was reduced ${ }^{48}$. The government has also pointed out that it is using alternative ways to provide aid, such as through a tax on financial transactions, ${ }^{49}$ but these do not appear as ODA. Furthermore, research highlights the highly 
francophone bias of French aid. ${ }^{50}$ Since 2014, the Secretary of State for Development is also responsible for" la Francophonie", a concept which refers to the link between France and most of its former colonies, which is based on historical, cultural and diplomatic ties. ${ }^{51}$ In 2013 and 2014, three of the top five recipients of French bilateral aid have substantial French-speaking populations (Morocco, Senegal and Cameroon)..$^{52}$ In addition, out of the sixteen countries identified as priority recipients of French bilateral aid, only two do not have French as official language. ${ }^{53}$ Although both France and the UK seem to view aid as a means to maintain or extend their sphere of influence, France is however more focused on its former empire and in this, does not display the same ambition as the UK.

\section{Adapting to a new reality since 2001 : security issues}

Although committed to its objectives since its creation, the DfID has sometimes had to adapt to a changing international context. In the aftermath of the 9/11 attacks, it was faced with the responsibility of allocating aid, without breaching its own rules of being guided only by the objective of fostering development. Aid money could not flow to countries or project solely with the aim of tackling security threats to the UK and fighting against terrorism. The main beneficiaries of aid had to be the people living in the country where aid would flow. However, it was possible for the DfID to argue that an insecure environment was not compatible with the fight against poverty since it favoured terrorism, violence and conflicts which would only worsen the plight of local populations. ${ }^{54}$ While the main aim of aid from DfID still remained tackling poverty, tackling security threats at the same time was compatible with the Department objectives because it helped foster the right environment to eradicate poverty. Help to reconstruct Iraq after 2003 was also seemingly not a priority on the DfID agenda because Iraq ranked as a middle-income country and the DfID had committed itself to a rule where $90 \%$ of its bilateral help had to be channeled to low-income countries. To give funds to Iraq without breaking its commitment, the DfID accelerated its withdrawal plans from a selection of middle-income countries and reduced its spending in others..$^{55}$ It would appear that some decisions are taken not solely on the basis of the need to eradicate poverty. The case of aid to Syria is telling since in 2010, as part of its reorganization, the DfID established a list of 28 priority countries. Syria was not one of them but the need to deal with Syria as a conflict-ridden country has made the UK decide to allocate aid to it nonetheless. To do so, it has reviewed some of its prioritised countries to make room for Syria. ${ }^{56}$

This has prompted some observers ${ }^{57}$ to comment that the renewed commitment of the British government to aid in the early 2000s was a way for the country to restore its tarnished image following its involvement in Iraq. Placing the focus on the positive international contributions of the UK is thus a way to improve its reputation..$^{58}$

\section{Migration issues}

In the eyes of the British government, eradicating poverty is not only a moral duty but it is also a way to tackle other issues such as that of migration. A White Paper entitled "Active Diplomacy for a Changing World; The UK's International Priorities" published in 2006 lists managing migration and combating illegal immigration as one of its nine Strategic Priorities. Securing the long-term economic development of the poorest 
countries in the world is arguably also a way of limiting the flow of migrants wishing to enter the UK.

While there is no doubt that the aid budget has not suffered from the crisis and the ensuing recession, the reasons explaining this fact are more difficult to identify. The aforementioned reasons highlight the tension that seems to exist behind the UK's commitment to aid. This tension is adequately illustrated by the title of a book published in 1991, "Britain's overseas aid since 1979: Between idealism and self-interest." 59 Although governed by moral principles and poverty alleviation considerations to some extent, British aid has also been characterized by the need to make sure meeting these principles also served other interests. This does not necessarily imply a selfish vision, where the sole beneficiary of British aid is the UK but it does mean that rules, commitments and policy orientations have been adapted to make sure that all the objectives, whether selfless or more strategic, were met. Another way of saying this is that although there is a humanitarian side to the DfID's work, it is not the actual main aim of the department. Its objective is to address the cause of poverty and not simply of alleviating poverty. ${ }^{60}$ This implies that obtaining long-term, sustainable economic growth, working towards conflict resolution, improving governance, fighting corruption and investing in research and development is also on the agenda of the DfID. ${ }^{61}$ Providing aid is also a way of reasserting the UK's belief that it has a role to play on the international scene as a prominent country. As such, it seems unlikely that aid from the UK will decrease dramatically, given the repeated public commitment of the previous coalition government to reach, then maintain the 0.7 ratio and the fact that Justine Greening, the current Secretary of State for International Department in the Conservative government, has been in place since 2012 when the coalition was still in power. However, the shrinking budget is also a reality, so rather than the volume of ODA, it is the type of aid that is likely to evolve, with an increase in concessional aid and a decrease in grants, a trend which may already have started.

\section{BIBLIOGRAPHY}

Barder Owen, "Reforming Development Assistance: Lessons from the UK Experience" (2005).

Blair Tony, “Chicago speech", [Online], <http://www.britishpoliticalspeech.org/ speecharchive.htm?speech=279>, [6 $6^{\text {th }}$ June 2015].

Bose Anuradha \& Burnell Peter (Eds.), Britain's overseas aid since 1979: Between idealism and selfinterest, (Manchester, 1991).

BREUNING Marijke, "Words and Deeds: Foreign Assistance Rhetoric and Policy Behaviour in the Netherlands, Belgium and the United Kingdom", International Studies Quarterly, Vol. 39, No.2, (1995), pp.235-254.

CAMERON David, "Speech on the UK's strength and security in the EU" [Online] <https:// www.gov.uk/government/speeches/pm-speech-on-the-uks-strength-and-security-in-the-eu-9may-2016>, [17th May 2016]. 
Development Initiative, Investment to End Poverty: Real money, real choices, real lives (Bristol, 2013).

DfID, Statistics on International Development 2014 (London, 2014).

Business Plan 2011-2015, London, 2011. Retrieved from <https://www.gov.uk/government/ uploads/system/uploads/attachment_data/file/67658/DFID-business-plan.pdf>, [15 ${ }^{\text {th }}$ May 2015]

UK aid: Changing Lives, Delivering Results, (London, 2011).

Statistics on International Development 2005/06-2009/10 (London, 2010).

DfID, FCO \& MOD, Building Stability Overseas Strategy, (London, 2011).

FRENCH DIPLOMACY, “Infographie "L'aide au développement française : les pays pauvres prioritaires" [Online], <http://www.diplomatie.gouv.fr/fr/politique-etrangere-de-la-france/aideau-developpement/dispositif-institutionnel-et-canaux-d-acheminement-de-l-aide-francaise/ canaux-d-acheminement-de-l-aide/article/infographie-l-aide-au>, [27 $7^{\text {th }}$ May 2016]

Führer, Helmut, The Story of Official Development Assistance, A History of the Development Assistance Committee and the Development Cooperation Directorate in Dates, Names and Figures (Paris, 1996).

Gagnon Michelle L. \& Labonte, Ronald, "Understanding How and Why Health is Integrated into Foreign Policy - A Case Study of Health is Global, a UK, Government Strategy 2008-2013”, Globalization and Health, Vol. 9 No. 24, (2013).

Glennie Jonathan, “Finally, the UK's Labour Party Seems to Know Its Own Mind on Development" - The Guardian, $4^{\text {th }}$ October 2012. Retrieved from

<http://www.theguardian.com/global-development/poverty-matters/2012/oct/04/uk-labourparty-own-mind-development> [14 ${ }^{\text {th }}$ June 2015]

GREENHILL Robert, "Making a Difference? External Views on Canada's International Impact”, The Interim Report of the External Voices Project, (Toronto, 2005).

Hashmi Nabil, Birdsall, Nancy and Kharas, Homi, The Quality of Official Development Assistance 2014, CGD Brief, (London, 2014).

INTERNATIONAL DEVELOPMENT COMMITTEE, “UK Aid: Allocation of Resources: Interim Report", Third Report of Session 2015-16, House of Commons, March (London, 2016).

Lunn Jon, Miller, Vaughne \& Smith, Ben, “British foreign policy since 1997”, Research Paper 08/56 (London, 2008).

MCKINLAY Robert D., “The Aid Relationship: A Foreign Policy Model and Interpretation of the Distribution of Official Bilateral Economic Aid of the United States, the United Kingdom, France, and Germany, 1660-1970", Comparative Political Studies, Vol. 11, No.4, (1979), pp.411-464.

MITCHELL Andrew, “Bilateral and Multilateral Aid Reviews” [Online], <https://www.gov.uk/ government/speeches/statement-by-the-secretary-of-state-for-international-development-thebilateral-and-multilateral-aid-reviews>, [17th May 2016].

National Audit Office, The Performance of the Department for International Development 2013-14 (London, 2014).

OECD, "DAC website" [Online] <http://www.oecd.org/dac/> [2 ${ }^{\text {nd }}$ June 2016].

Is it ODA? Factsheet (Paris, 2008).

PACQUEMENT François, "Le système d'aide au développement de la France et du Royaume-Uni : points de repère sur cinquante ans d'évolutions depuis la decolonisation", Revue international de politique de développement [Online], <http://poldev.revues.org/114> [16th May 2016] 
RAM Rati "Roles of Bilateral and Multilateral Aid in Economic Growth of Developing Countries", Kyklos, Vol. 56, No.1, (2003), pp.95-110.

SAPIN Michel, “Projet de Loi de Finances pour 2015”, [Online] <http://www.assembleenationale.fr/14/budget/plf2015/commissions_elargies/cr/c005.asp> [27 ${ }^{\text {th }}$ May 2016]

SCHRAEDER Peter J., HOOK Steven W. and TAYLOR Bruce, "Clarifying the Foreign Aid Puzzle: A Comparison of American, Japanese, French and Swedish Aid Flows", World Politics, Vol.50, No.2, (1998), pp.294-323.

Seager, Ashley, "Britain now the world's second largest aid donor". Retrieved from

The Guardian, $5^{\text {th }}$ October 2007. Retrieved from <http://www.theguardian.com/politics/2007/ oct/05/uk.g8> [6 $6^{\text {th }}$ June 2015].

STOKKE Olav (Ed.), Western Middle Powers and Global Poverty: The Determinants of the Aid Policies of Canada, Denmark, the Netherlands, Norway and Sweden, (Uppsala, 1989).

The Brookings Institution, [Online], <http://www.brookings.edu/about\#research-programs $/>\left[7^{\text {th }}\right.$ June 2015].

\section{NOTES}

1. BARDER Owen, "Reforming Development Assistance: Lessons from the UK Experience", Working Paper 70 (London, 2005), p. 4.

2. OECD Stats, [Online], <http://www.oecd.org/dac/stats/ officialdevelopmentassistancedefInitionandcoverage.htm>, [27 $7^{\text {th }}$ May 2015].

3. These are Sweden in 1974, the Netherlands in 1975, Norway in 1976 and Denmark in 1978 - see FUHRER Helmut, The Story of Official Development Assistance, A History of the Development Assistance Committee and the Development Co-operation Directorate in Dates, Names and Figures (Paris, 1996), p. 26.

4. DfID, Statistics on International Development 2014 (London, 2014), p. 9.

5. DfID, Statistics on International Development 2005/06-2009/10 (London, 2010), p. 3.

6. OECD, Is it ODA? Factsheet, (Paris, 2008)

7. OECD Stats, [Online], <http://www.oecd.org/dac/>, [27 $7^{\text {th }}$ May 2015].

8. Development initiative, Investment to End Poverty: Real money, real choices, real lives (Bristol, 2013), p. 80.

9. Ibid. p. 214.

10. Ibid. p. 3.

11. Ibid. p. 43.

12. Ibid. p. 59.

13. OECD, [Online], <http://www.oecd.org/newsroom/aid-to-developing-countries-reboundsin-2013-to-reach-an-all-time-high.htm>, [27 ${ }^{\text {th }}$ May 2015].

14. OECD, [Online], <http://www.oecd.org/newsroom/ aidtopoorcountriesslipsfurtherasgovernmentstightenbudgets.htm $>$, [27 ${ }^{\text {th }}$ May 2015].

15. The apparent drop for the period 2005-2007 is in fact the result of an exceptional debt relief in 2005 and 2006 in favour of Nigeria and Iraq, decided at the 2005 Gleneagles Summit. Since debt relief is included in ODA statistics, aid recorded in 2005 and 2006 was exceptionally higher than usual, hence the apparent drop thereafter. This exceptional debt relief apart, the growth was steady up till 2010.

16. The official position is to "focus UK aid more tightly on the countries where the UK is well placed to have a significant long-term impact on poverty". See for instance the speech of former 
Secretary of State for International Development Andrew Mitchell to Parliament in 2011 [Online], <https://www.gov.uk/government/speeches/statement-by-the-secretary-of-state-forinternational-development-the-bilateral-and-multilateral-aid-reviews>, [17th May 2016]

17. In total, 128 countries received ODA from the UK in 2011, which amounts to $33 \%$ of British development aid going to $28 \%$ of all beneficiaries for that year.

18. DeVelopment Initiative, Investment to End Poverty, op.cit. p. 212.

19. If we discard years 2005 and 2006 which showed exceptional levels of bilateral ODA due to high amounts of debt relief for Nigeria and Iraq, the average ODA channelled through multilateral organisations for the periods $2000-2004$ and 2007-2010 was $36 \%$ and for $2011-2014$, it was of $39.4 \%$.

20. The DfID has endeavoured to enhance its contribution to multilateral aid since it considers that it can have more leverage thanks to pooled resources - DfID, FCO \& MOD, Building Stability Overseas Strategy, (London 2011), p.18. The view that multilateral aid increases efficiency is not shared by Ram who deems that multilateral ODA does not work - RAM Rati "Roles of Bilateral and Multilateral Aid in Economic Growth of Developing Countries", Kyklos, Vol. 56, No.1, 2003, pp.95-110.

21. The sources for these calculations are taken from various issues of DFID and OECD statistics. Given likely methodological differences in calculation and changes in the modes of reporting over the years, there are most likely some discrepancies.

22. These past few years, less ODA took the form of debt cancellation and as such, the share of bilateral ODA which is not transferred to recipient countries is smaller.

23. The guidelines provided by HM Treasury would seem to confirm this. Indeed, a report of the International Development Committee to the House of Commons states: "HM Treasury rules require DFID to spend $£ 5$ billion of 'non-fiscal capital' over this CSR [Comprehensive Spending Review] period. Non-fiscal capital is spending, such as loans, equity investments and certain contributions to multilateral development banks, which is expected to generate at least some financial return to DFIF in the future and therefore does not impact net public sector debt." - I NTERNATIONAL DEVELOPMENT COMMITTEE, “UK Aid: Allocation of Resources: Interim Report", Third Report of Session 2015-16, House of Commons, March 2016, p.21.

24. BARDER Owen, "Reforming Development Assistance", op. cit., p. 13.

25. LUNN Jon, MILLER Vaughne and SMITH Ben, “British foreign policy since 1997", Research Paper 08/56 (London, 2008)

26. BLAIR Tony, 'Chicago Speech' [Online], <http://www.britishpoliticalspeech.org/speecharchive.htm?speech=279>, [ $6^{\text {th }}$ June 2015].

27. The 1964-1967 Ministry of Overseas Development was also a separate Government Cabinet. See BARDER Owen, "Reforming Development Assistance", op. cit., p. 7.

28. LUNN Jon, MILLER Vaughne and SMITH Ben, "British foreign policy since 1997", op. cit., p. 9.

29. BARDER Owen, "Reforming Development Assistance", op. cit., p. 16.

30. DeVelopment initiatives, Investment to End Poverty, op. cit., p. 214.

31. SEAGER Ashley, "Britain now the world's second largest aid donor", The Guardian, $5^{\text {th }}$ October 2007, [Online], http://www.theguardian.com/politics/ [6 $6^{\text {th }}$ June 2015]

32. Andrew Mitchell, Secretary of State for International Development from 2010 to 2012 said "There is not a Conservative, Liberal Democrat or Labour development policy, but a British one" - GLENNIE Jonathan, "Finally, the UK's Labour Party Seems to Know Its Own Mind on Development" -The Guardian, [Online], $4^{\text {th }}$ October 2012, <http://www.theguardian.com/globaldevelopment/poverty-matters/2012/oct/04/uk-labour-party-own-mind-development> [14 ${ }^{\text {th }}$ June 2015]

33. National Audit office, The Performance of the Department for International Development 2013-14, (London, 2014), p. 18. 
34. DfID, FCO \& MOD, Building Stability Overseas Strategy, op. cit, p. 24.

35. Refer to note 24 .

36. In his speech in Chicago where he expounded his international doctrine in 1999, Tony Blair said: "We have finally done away with the false proposition that we must choose between two diverging paths - the Transatlantic relationship or Europe. For the first time in the last three decades, we have a government that is both pro-Europe and pro-American" - BRITISH POLITICAL SPEECH, [Online], op. cit.

37. For example, in a review of Canada's international development strategy, the DfID was described as "by far the best organization internationally" - GREENHILL Robert, "Making a Difference? External Views on Canada's International Impact", The Interim Report of the External Voices Project, (Toronto, 2005), p.28.

38. In their own words, "The Brookings Institution is a private nonprofit organization devoted to independent research and innovative policy solutions". [Online] http://www.brookings.edu/ about\#research-programs/ [7 $7^{\text {th }}$ June 2015]

39. HASHMI Nabil, BIRDSALl Nancy \& KHARAS Homi, The Quality of Official Development Assistance 2014, CGD Brief, (London, 2014).

40. DfID, UK aid: Changing Lives, Delivering Results (London, 2011), p. 32.

41. SCHRAEDER Peter J., HOOK Steven W. and TAYLOR Bruce, "Clarifying the Foreign Aid Puzzle: A Comparison of American, Japanese, French and Swedish Aid Flows", World Politics, Vol.50, No.2, (1998), pp.294-323.

42. For comparative studies on donor motivation, see for instance MCKINLAY Robert D., "The Aid Relationship: A Foreign Policy Model and Interpretation of the Distribution of official Bilateral Economic Aid of the United States, the United Kingdom, France, and Germany, 1660-1970", Comparative Political Studies, Vol. 11, No.4, (1979), pp.411-464; BREUNING Marijke, "Words and Deeds: Foreign Assistance Rhetoric and Policy Behaviour in the Netherlands, Belgium and the United Kingdom", International Studies Quarterly, Vol. 39, No.2, (1995), pp.235-254; PACQUEMENT François, "Le système d'aide au développement de la France et du Royaume-Uni : points de repère sur cinquante ans d'évolutions depuis la decolonisation", Revue international de politique de développement [Online], http://poldev.revues.org/114 [16th May 2016]; STOKKE Olav (Ed.), Western Middle Powers and Global Poverty: The Determinants of the Aid Policies of Canada, Denmark, the Netherlands, Norway and Sweden, (Uppsala,1989); SCHRAEDER Peter J., HOOK Steven W. and T AYLOR Bruce, "Clarifying the Foreign Aid Puzzle", op. cit.

43. In this respect, it is interesting to note that two empirical studies reach the conclusion that British aid often serves the purpose of extending British Influence. See MCKINLAY Robert D, "The Aid Relationship", op. cit; Marijke Breuning, "Words and Deeds", op. cit.

44. In the June 2016 referendum on whether the UK should leave the European Union, Conservative Prime Minister David Cameron is campaigning against an exit. In a speech delivered in May 2016, he recalled the importance of both the EU and the US for the UK - PM speech on the UK's strength and security in the EU [Online] <https://www.gov.uk/government/speeches/pmspeech-on-the-uks-strength-and-security-in-the-eu-9-may-2016>, [17th May 2016].

45. Several declarations have been made by various politicians including former Labour Prime Minister Tony Blair, former Liberal Democrat Deputy Prime Minister Nick Clegg and Current Conservative Secretary of State for International Development, Justine Greening.

46. The International Development (Official Development Assistance Target) Act was passed in early 2015. It puts into legislation the target of spending at least $0.7 \%$ of national income on aid.

47. SCHRAEDER Peter J., HOOK Steven W. and TAYLOR Bruce, "Clarifying the Foreign Aid Puzzle", op. cit. pp. 310-311.

48. While speaking at the National Assembly in 2014, the Minister of Finance, Michel Sapin said: "Comme ministre des Finances, je me dois de rappeler d'abord combine le cadre budgétaire national est constraint. A ce titre, l'aide publique au développement participe aux efforts 
collectifs de redressement des comptes publics, enregistrant ainsi une baisse strict sensu en 2015 par rapport à 2014. Toutefois, cette baisse est compensée partiellement par les financements innovants. » - The full text can be accessed at [Online] <http://www.assemblee-nationale.fr/14/ budget/plf2015/commissions_elargies/cr/c005.asp> [27 $7^{\text {th }}$ May 2016]

49. Such a tax has been in place since 2012 (Taxe sur les Transactions Financières) and a percentage of its product is allocated to development projects.

50. SCHRAEDER Peter J., HOOK Steven W. and TAYLOR Bruce, "Clarifying the Foreign Aid Puzzle", op. cit., pp.317-319

51. See OECD stats for more recent years

52. OECD Statistics database, [Online], <https://public.tableau.com/views/AidAtAGlance/ DACmembers?:embed=y\&:display_count=no?\&:showVizHome=no\#1>, [27 ${ }^{\text {th }}$ May 2016]

53. FRENCH DIPLOMACY, [Online], <http://www.diplomatie.gouv.fr/fr/politique-etrangere-dela-france/aide-au-developpement/dispositif-institutionnel-et-canaux-d-acheminement-de-l-

aide-francaise/canaux-d-acheminement-de-l-aide/article/infographie-l-aide-au>, [27 ${ }^{\text {th }}$ May 2016]

54. BARDER Owen, "Reforming Development Assistance", op. cit., p. 31.

55. Ibid. p. 21.

56. LUNN Jon, MiLLER Vaughne and SMITH Ben, “British foreign policy since 1997”, op. cit., p. 25.

57. GAGNON Michelle L. \& LABONTÉ Ronald, “ Understanding How and Why Health is Integrated into Foreign Policy - A Case Study of Health is Global, a UK, Government Strategy 2008-2013", Globalization and Health, vol. 9, $\mathrm{n}^{\circ}$ 24, (2013), p. 4.

58. Ibid.

59. BOSE Anuradha and BURNELL Peter (Eds.), Britain's overseas aid since 1979: Between idealism and self-interest (Manchester, 1991).

60. BARDER Owen, "Reforming Development Assistance”, op. cit., p. 23.

61. DfID, Business Plan 2011-2015 (London, 2011). Retrieved from <https://www.gov.uk/ government/upl

oads/system/uploads/attachment_data/file/67658/DFID-business-plan.pdf> [15 ${ }^{\text {th }}$ May 2015]

\section{ABSTRACTS}

In the wake of the financial crisis, which started in the United States in 2007 and given the problems that developed countries had to face internally, Official Development Assistance (ODA) was expected to be negatively affected. However, in 2010, net ODA was actually $63 \%$ above its 2000 level. So we can wonder if development aid has proven to be one of the few areas which resisted the onslaught of the crisis. The paper will focus on the case of British assistance in recent times. It is indeed both interesting and relevant to pay special attention to the British example due to its colonial history; Britain has always stood out when it came to development aid and has displayed a much more extended vision of aid than what is strictly required by the United Nations (UN) or World Bank standards. British ODA has actually steadily increased since 2007. So far, the United Kingdom (UK) has clearly shown a solid attachment to development and is amongst the few advanced economies that fulfil the target of allocating 0.7 percent of their Gross National Income to ODA. Given the motivations of the British government in its commitment to aid, it is argued that Britain is likely to continue its good performance as a provider of ODA. 
Dans le sillage de la crise financière qui débuta aux Etats-Unis en 2007 et compte tenu des problèmes qui affectent les pays développés, on aurait pu s'attendre à un recul de l'aide publique au développement (APD). Cependant, en 2010 l'APD avait augmenté de 63\% par rapport à l'an 2000. On peut se demander si l'aide au développement est l'une des rares sphères à avoir échappé aux conséquences de la crise. L'article s'intéresse plus particulièrement à l'aide publique au développement britannique ces dernières années. A cet égard, le Royaume-Uni est un sujet d'étude à la fois intéressant et pertinent car en tant qu'ancienne puissance coloniale, il ne s'est pas contenté de respecter les directives de l'Organisation des Nations-Unies (ONU) ou de la Banque mondiale en matière de développement. Il s'est toujours démarqué par sa conception plus étendue de la notion d'aide. Depuis 2007, l'APD britannique n'a cessé d'augmenter et la volonté des autorités d'y consacrer $0,7 \%$ du revenu national brut témoigne de leur engagement durable envers le développement. A la lumière des raisons qui motivent les autorités britanniques à respecter cet engagement, il semble probable que le gouvernement maintiendra le cap en tant que contributeur modèle à l'aide publique au développement.

\section{INDEX}

Mots-clés: Mots clés : aide publique au développement (APD), motivation à contribuer à l'APD, politique étrangère britannique, aide humanitaire, Department for International Development (DfID)

Keywords: Keywords: Official Development Assistance (ODA), ODA donor motivation, British foreign policy, humanitarian aid, Department for International Development (DfID)

\section{AUTHOR}

ONDINE AZA

Université Cergy Pontoise Equipe CERVEPAS/CREW 